AI Qalam: Jurnal Ilmiah Keagamaan dan Kemasyarakatan
https://jurnal.stiq-amuntai.ac.id/index.php/al-qalam
P-ISSN: 1907-4174; E-ISSN: 2621-0681
DOI : 10.35931/aq.v16i2. 869

\title{
PENGELOLAAN PEMBELAJARAN MAHARAH ISTIMA’ DAN KALAM OLEH HIMPUNAN MAHASISWA PRODI PBA STIQ AMUNTAI
}

\author{
H. Alfianor, Lc., M.Pd.I \\ Dosen, STIQ Amuntai, Kalimantan Selatan, Indonesia \\ hajialfianorlc@gmail.com
}

\begin{abstract}
Abstrak
Pengelolaan pembelajaran merupakan hal yang sangat penting dan utama untuk memudahkan jalannya suatu pembelajaran. Pengelolaan yang baik dan benar akan memudahkan mencapai tujuan pembelajaran dan menghasilkan output yang sesuai dengan tujuan pembelajaran. Namun, jika pengelolaan pembelajaran tidak disusun dan dirancang dengan baik dan benar maka dalam proses pembelajaran akan mengalami problem dan kendala yang menyebabkan tidak stabilnya pembelajaran. Penelitian ini bertujuan untuk mengeksplorasi bagaimana pengelolaan pembelajaran maharah istima' dan maharah kalam oleh HMP PBA STIQ Amuntai. Penelitian ini menggunakan metode kualitatif, Teknik pengumpulan data menggunakan observasi, wawancara dan dokumentasi. Adapun Teknik analisis data menggunakan Teknik Miles dan Huberman yaitu reduksi data, display data dan verifikasi data. Hasil penelitian ini memberikan gambaran dan informasi bahwa pengelolaan pembelajaran maharah istima' dan maharah kalam oleh HMP PBA STIQ Amuntai sudah tersusun secara terstruktur dan berjalan dengan baik. Namun, ada beberapa hal yang masih belum terpenuhi sebagaimana layaknya pengelolaan pembelajaran yang baik dan benar. Seperti halnya belum adanya penyusunan evaluasi pembelajaran yang benar-benar dapat mengukur dan mengetahui berhasilnya suatu pembelajaran. Penelitian diharapkan dapat memberikan kontribusi kepada para pengajar dimanapun berada, baik secara teoretis maupun secara praktis. Sehingga diharapkan juga dengan adanya penelitian ini bisa menjadi masukan bagi HMP PBA STIQ Amuntai untuk lebih menyempurnakan dan memperbaiki program atau pengelolaan pembelajaran maharah istima' dan maharah kalam.
\end{abstract}

Kata Kunci: Pengelolaan, Maharah Istima', Mahaah Kalam, HMP PBA STIQ Amuntai

\section{PENDAHULUAN}

Di penjuru dunia Alquran dan hadits yang bahasa Arab sebagai bahasanya, menjadi pedoman dan tuntunan umat Islam. Oleh sebab itu bagi kaum muslim bahasa Arab menjadi suatu yang harus dikuasi jika hendak memahami ajaran Islam secara sempurna. Selain itu, bahasa Arabpun telah menjadi bahasa Internasional, sehingga tidak hanya negara Islam saja melainkan negara-negara yang berada diseluruh dunia. Hal demikian menjadi mutlak bahwa bahasa Arab menjadi sutau hal mutlak baik untuk memahami ajaran Islam dan menjadi suatu sarana bagi ilmu pengetahuan sekaligus menjadi sarana untuk bisa bergaul dengan bangsa-bangsa di dunia. Hal ini

Al Qalam: Jurnal Ilmiah Keagamaan dan Kemasyarakatan Vol. 16, No. 2

Maret - April 2022 
H. Alfianor, Lc., M.Pd.I: Pengelolaan Pembelajaran Maharah Istima' dan Kalam Oleh Himpunan Mahasiswa Prodi PBA STIQ Amuntai

sebagaimana yang telah dikatakan oleh Abdul Majid yang mengatakan bahwa seperti yang kita ketahui bahwa bahasa Arab memiliki kedudukan yang istimewa, bahasa Arab sebagai bahasa persatuan umat Islam di dunia, dan tidak hanya sebagai bahasa peradaban. Bahasa Arab adalah bahasa Alquran yang di dalamnya terdapat firman Allah yang dijadikan sebagai pedoman bagi umat islam, tidak hanya itu, bahasa Arab juga memiliki uslub dan sastra yang bermutu dan tinggi yang membuat manusia tidak mampu menandinginya. ${ }^{1}$

Bahasa Arab di dunia Pendidikan Islam adalah menjadi bahasa pengantar, karena bahasa Arab memiliki keunggulan dan keistimewaan disbanding dengan bahasa lain. Hal ini dibuktikan bahwa Allah swt memilih bahasa Arab sebagai bahasa Alquran, begitupun hadits juga menggunakan bahasa Arab, sebab Nabi Muhammad saw dilahirkan sebagai orang Arab, dengan begitu secara otomatis bahasa yang digunakan sehari-hari juga menggunakan bahasa Arab. Di antara keistimewaan bahasa Arab tersebut adalah pada setiap huruf-hurufnya yang singkat mampu menampung suatu informasi yang padat. Hanya dengan beberapa ungkapan saja (dua atau tiga kata) yang berbahasa Arab, mampu menjelaskan secara mendalam dan luas. Dan ini bukti bahwa bahasa Arab memiliki keistimewaan dan kemampuan yang tentunya tidak ditemui pada bahasa selain bahasa Arab. Pada semua bahasa hampir semunya berasal dari kata serapan bahasa Arab.

Bahasa arab hampir selalu di ajarkan diberbagai jenjang Pendidikan, baik formal maupun non formal. Karena mengingat bahasa Arab merupakan bahasa yang tidak bisa lepas dari kehidupan orang Islam. Orang islam hampir setiap harinya selalu menggunakan bahasa Arab, baik dalam berkomunikasi (bagi yang lingkungan menggunakan bahasa Arab) maupun dalam ibadah seperti membaca Alquran, membaca hadits, shalat dan belajar ilmu agama (belajar dengan kitab klasik). Oleh karena itu, kiranya pembelajaran bahasa Arab dianggap sangat penting dan perlu diajarkan di berbagai jenjang Pendidikan.

Setidaknya bagi seseorang yang ingin mempelajarai Bahasa Arab, terutama bagi warga negara Indonesia bahasa Arab merupakan Bahasa Asing. Oleh karena itu, seharunya seseorang mempelajarinya dengan sungguh-sungguh tentang kompetensi Bahasa Arab. Yaitu keterampilan menyimak, keterampilan berbicara, keterampilan membaca dan keterampilan menulis. Keempat kompetensi kebahasaan itu merupakan keterampilan yang harus dikuasai dan dipahami oleh seorang yang mempelajari Bahasa arab, agar dalam mempelajari Bahasa arab mudah dan cepat menguasai Bahasa arab dengan baik dan benar.

Namun, mengingat bahwa bahasa arab adalah bahasa yang istimewa, dan banyak memiliki kaidah-kaidah atau bahasa yang memiliki kekhasan tersendiri dibanding dengan bahasa

${ }^{1}$ Abdul Majid, Perencanaan Pembelajaran (Bandung: PT Remaja Rosdakarya, 2007), h. 112.

Al Qalam: Jurnal Ilmiah Keagamaan dan Kemasyarakatan Vol. 16, No. 2 Maret - April 2022 
H. Alfianor, Lc., M.Pd.I: Pengelolaan Pembelajaran Maharah Istima' dan Kalam Oleh Himpunan Mahasiswa Prodi PBA STIQ Amuntai

lain. Hal tersebut menyebakan banyak seorang peserta didik (siswa dan mahasiswa) yang mengalami kesulitan (problem) ketika belajar bahasa Arab. Oleh karena itu, diperlukan pengelolaan pada pembelajaran bahasa Arab yang memang benar-benar mempermudah siswa ketika belajar bahasa Arab.

Agar hasil pembelajaran Bahasa Arab dapat berhasil dan berjalan dengan baik, maka perlu adanya pengelolaan pembelajaran bahasa yang baik. Sebagaimana yang ungkapkan oleh bahwa dengan mengelola sutau belajar mengajar (pembelajaran) Bahasa Arab yang baik, diharapkan para siswa mampu mengembangkan bakatnya serta memaksimalkan kompetensinya sehingga tercapai cita-cita serta prestasinya, tidak hanya membanggakan bagi dirinya dan sekolahnya, melainkan membanggakan bagi kedua orangtuanya. Prestasi memang dibutuhkan untuk menimbulkan rasa percaya diri yang positif, dengan begitu ketika nanti kembali dan terjun ke masyarakat, siswa senantiasa percaya diri dalam melaksanakan pekerjaannya.

Hal ini sebagaimana yang dilakukan oleh HMP PBA STIQ Amuntai yang melaksanakan pembelajaran maharah istima' dan maharah kalam, hal ini tentunya perlu untuk melakukan pengelolaan pembelajaran tersebut. Namun berdasarkan observasi dan wawancara sementara penulis dengan ketua HMP PBA STIQ Amuntai terkait dengan pengelolaan pembelajaran maharah istima' dan maharah kalam masih terlihat belum tersusun dengan secara terstruktur dan benar. Penulis menduga bahwa masih terdapat kekurangan dalam pengelolaan tersebut.

Oleh karana itu, menurut penulis perlu dan penting untuk diteliti lebih mendalam. Agar mendapatkan informasi yang lebih komprehensif dan kredibel. Mengingat pengelolaan pembelajaran Bahasa arab sangat perlu dan penting bagi siapa saja yang ingin mempelajari bahasa Arab. Oleh karena itu, penelitian ini bertujuan untuk mengeksplorasi tentang bagaimana Pengelolaan Pembelajaran Maharah Istima'dan Kalam Oleh Himpunan Mahasiswa Prodi PBA STIQ Amuntai.

\section{METODE PENELITIAN}

Penelitian ini menggunakan metode penelitian kualitatif. Penelitian kualitatif merupakan suatu penelitian yang bertujuan untuk menggambarkan dan menganalisis peristiwa social, fenomena, sikap, persepsi, kepercayaan, dan pemikiran orang secara kelompok maupuan secara individu. Data dan sumber data pada penelitian ini terdiri dari dari data utama (primer) dan data skunder (pendukung). Data utama adalah data yang diambil langsung ke lapangan melalui observasi, dokumentasi dan wawancara. Sedangkan data sekunder diambil dari buku-buku dan hasil penelitian yang relevan. Teknik pengumpulan data menggunakan teknik observasi,

Al Qalam: Jurnal Ilmiah Keagamaan dan Kemasyarakatan Vol. 16, No. 2 Maret - April 2022 
H. Alfianor, Lc., M.Pd.I: Pengelolaan Pembelajaran Maharah Istima' dan Kalam Oleh Himpunan Mahasiswa Prodi PBA STIQ Amuntai

dokumentasi dan wawancara. Sedangkan teknik analisis data menggunakan teknik reduksi data, display data dan verifikasi data.

\section{HASIL DAN PEMBAHASAN}

Berdasarkan hasil observasi dan wawancara yang penulis lakukan dengan Himpunan Mahasiswa Prodi PBA STIQ Amuntai dapat penulis uraikan berikut ini. Pengelolaan pembelajaran istima' dan kalam yang dilakukan oleh Himpunan Mahasiswa Prodi PBA STIQ Amuntai setidaknya terbagi menjadi tiga tahap, yaitu tahap perencanaan pembelajaran, tahap pelaksanaan pembelajaran, dan tahap evaluasi pembelajaran.

Hal ini sebagaimana yang telah paparkan oleh ketua HMP PBA STIQ, Ia mengatakan bahwa,

Pengelolaan pembelajaran maharah istima' dan maharah kalam setidaknya ada beberapa hal, yaitu tahap perencanaan, tahap pelaksaan dan tahap evaluasi. Pada tahap perencanaan kami Bersama kawan-kawan Menyusun materi dan RPP yaitu yang terdiri dari materi mufradat, istima' dan kalam, selain materi juga Menyusun RPP yang berisi tujuan pembelajaran, materi pembelajaran, Langkah-langkah pembelajaran. Adapun pada tahap pelaksanaan pembelajaran dengan alokasi waktu 120 menit dengan pembagian waktu 5 menit (pendahuluan), 15 menit (materi mufrodat), 10 menit (materi istima'), 60 menit (materi Kalam), dan 30 menit (ta'aruf), metode yang kami gunakan adalah metode menyesuaikan dengan materi yang akan disampaikan, namun biasanya menggunakan metode demonstrasi, dan untuk medianya adalah media audio visual. Sedangkan tahap evaluasi ini dengan menampilkan siswa atau peserta didik beribicara di muka umum. (wawancara, September 2021).

Dari hasil wawancara di atas dapat dirumuskan bahwa pengelolaan pembelajaran maharah istima' dan maharah kalam Himpunan Mahasiswa Prodi PBA STIQ Amuntai adalah sebagai berikut:

1. Perencanaan Pembelajaran

Pada tahap perencanaan kami bersama kawan-kawan menyusun materi dan RPP yaitu yang terdiri dari materi mufradat, istima' dan kalam, selain materi juga menyusun RPP yang berisi tujuan pembelajaran, materi pembelajaran, dan langkah-langkah pembelajaran.

Al Qalam: Jurnal Ilmiah Keagamaan dan Kemasyarakatan Vol. 16, No. 2 Maret - April 2022 
H. Alfianor, Lc., M.Pd.I: Pengelolaan Pembelajaran Maharah Istima' dan Kalam Oleh Himpunan Mahasiswa Prodi PBA STIQ Amuntai

Perencanaan pembelajaran secara bahasa terdiri dari dua kata yaitu perencanaan dan pembelajaran. Perencanaan sendiri memiliki arti yaitu suatu keputusan yang harus diambil oleh seseorang untuk mencapai suatu tujuan. ${ }^{2}$ Tujuan tersebut harus disusun dan arahkan dengan jelas dan struktur, karena terget itulah yang akan menjadi titik fokus dalam menentukan langkah selanjutnya. ${ }^{3}$ Sedangkan pembelajaran adalah suatu usaha yang dilakukan oleh seorang guru untuk membelajarkan peserta didik agar bisa tumbuh dan berkembang sesuai dengan tujuan dan maksud diciptakannya manusia itu sendiri. ${ }^{4}$

Jika diperhatikan dipahami uraian tenteng perencanaan pembelajaran, maka perencanaan pembelajaran merupakan hal yang sangat penting agar tujuan pembelajaran berjalan dengan lancar dan berhasil. Hal ini sebagaimana yang dikatakan oleh Nurlaila, Ia mengatakan bahwa perencanaan pembelajaran yang disusun oleh pendidik adalah posisi yang paling penting, hal ini sebagai salah satu indicator bahwa guru itu adalah guru yang professional. Bahkan Ia juga mempertegas bahwa jika guru yang tidak merencakan pembelajaran terlebih dahulu, maka bisa dikatakan guru itu tidak profesional. ${ }^{5}$

Menurut Hamalik ada tiga hal yang harus diperhatikan ketika seseorang Menyusun atau membuat perencanaan pembelajaran, yaitu sumber-sumber belajar yang tersedia, kondisi atau keadaan siswa harus menjadi perhatian yang penting, dan tentunya siap dan bertanggung jawab penuh atas apa yang telah menjadi tugas dan fungsinya sesuai perencanaan yang telah disusun tersebut. ${ }^{6}$ Namun masalahnya terkadang guru malas dalam menyusun perencanaan pembelajaran, malas menyusun, merancang dan mempraktikkanya saat menjalankannya pada pembelajaran berlangsung.

Hunt disini tampaknya memberikan solusi atas permasalahan tersebut, yaitu guru harus memahami dan mengetahui hal-hal yang berkaitan dengan perencanaan pembelajaran yang baik, ${ }^{7}$ di antara unsur-unsur tersebut adalah menelaah dan mendiagnosis kebutuhan peserta didik, menentukan tujuan yang hendak dicapai, menggunakan strategi, metode dan sintaks yang sesuai materi, agar tujuan pembelajaran tercapai, dan yang terakhir adalah kriteria evaluasi. ${ }^{8} \mathrm{Jika}$ diperhatikan lagi, bahwa perencanaan pembelajaran memang identik dengan persiapan mengajar.

24.

${ }^{2}$ Wina Sanjaya, Perencanaan dan Desain Sistem Pembelajaran (Jakarta: Kencana, 2015), h. 23-

${ }^{3}$ Sanjaya, h. $24-25$.

${ }^{4}$ Nurlaila, "Urgensi Perencanaan Pembelajaran Dalam Peningkatan Profesionalisme Guru," Jurnal Ilmiah Sustainable 1, no. 1 (2018).

${ }_{6}^{5}$ Nurlaila.

${ }^{6}$ Oemar Hamalik, Perencanaan Pengajaran Berdasarkan Sistem (Jakarta: PT Bumi Aksara, 2009), h. 50 .

${ }^{7}$ Abdul Majid, Perencanaan Pembelajaran (Bandung: Remaja Rosdakarya, 2011), h. 94.

${ }^{8}$ Majid, h. 94.

Al Qalam: Jurnal Ilmiah Keagamaan dan Kemasyarakatan Vol. 16, No. 2 Maret - April 2022 
H. Alfianor, Lc., M.Pd.I: Pengelolaan Pembelajaran Maharah Istima' dan Kalam Oleh Himpunan Mahasiswa Prodi PBA STIQ Amuntai

oleh karena itu dalam menyusun perencanaan pembelajaran tersebut harus sesuai dengan minat dan ketertarikan peserta didik terhadap materi yang akan menjadi bahan pembelajaran. ${ }^{9}$

Jika dilihat dari hasil wawancara dengan ketua HMP PBA STIQ Amuntai, bahwa dalam melakukan penyusunan perencanaan pembelajaran maharah istima' dan maharah kalam sudah terstruktur dengan baik, namun dalam RPP belum dituliskan dan disebutkan tentang evaluasinya. Hal ini terlihat di RPP, hanya sampai pada langkah-langkah pembelajaran saja, sedangkan untuk evaluasi belum ada, meskipun dalam praktiknya evaluasi sudah dijalannya, namun seharusnya di RPP juga harus disusun, agar perencanaan pembelajaran tersebut tersusun dengan baik dan terstruktur.

2. Pelaksanaan Pembelajaran

Adapun pada tahap pelaksanaan pembelajaran dengan alokasi waktu 120 menit dengan pembagian waktu 5 menit (pendahuluan), 15 menit (materi mufrodat), 10 menit (materi istima'), 60 menit (materi Kalam), dan 30 menit (ta'aruf), metode yang kami gunakan adalah metode menyesuaikan dengan materi yang akan disampaikan, namun biasanya menggunakan metode demonstrasi, dan untuk medianya adalah media audio visual.

Pelaksanaan atau proses pembelajaran merupakan suatu aktivitas antara seorang guru dan murid yang saling berinteraksi. Pelaksanaan pembelajaran ini juga sebagai implementasi dari perencanaan pembelajaran yang telah disusun dan rancang sebelumnya. Menurut Setyo Sari pembelajaran hendaknya fokus pada proses mendidik, dan ini merupakan tugas utama bagi seorang guru. Tugas mendidik ini sangat berhubungan dengan pertumbuhan dan perkembangan peserta didik menjadi manusia yang dewasa. Disebutkan juga bahwa tanda-tanda manusia dewasa adalah ditandai dengan adanya berpikir yang dewasa secara intelektual, mengontrol emosional, mampu membedakan perbuatan dan tindakan baik atau buruk, mampu menilai hal yang indah atau tidak indah, mampu bekerjasama dengan orang lain, dan lain sebagainya. ${ }^{10}$

Peristiwa atau proses pembelajaran ini setidaknya mencakup adanya menarik perhatian, penyampaian tujuan pembelajaran, memberikan stimulus kepada peserta didik, menyajikan bahan atau materi pelajaran, memberikan latihan-latihan secara terbimbing, menampilkan aktivitas psikomotorik atau unjuk kerja, memberikan umpan balik, menilai hasil unjuk kerja yang telah

${ }^{9}$ Faizal Djabidi, Manajemen Pengelolaan Kelas (Malang: Madani, 2017), h. 50.

10 Punaji Setyosari, "Pembelajaran Kolaborasi Landasan untuk Mengembangkan Keterampilan Sosial, Rasa Saling Menghargai dan Tanggung Jawab," Pidato Pengukuhan Pendidik Besar dalam Bidang Ilmu TEP pada FIP UM disampaikan pada sidang terbuka Senat UM 14 (2009).

Al Qalam: Jurnal Ilmiah Keagamaan dan Kemasyarakatan Vol. 16, No. 2 Maret - April 2022 
H. Alfianor, Lc., M.Pd.I: Pengelolaan Pembelajaran Maharah Istima' dan Kalam Oleh Himpunan Mahasiswa Prodi PBA STIQ Amuntai

dilakukan oleh peserta didik, dan meningkatkan retensi dan transfer. Berkaitan dengan tugas tersebut, tampaknya Permendiknas membagi tugas atau kegiatan utama, yaitu adanya kegiatan pendahuluan, kegiatan inti, yang mencakup di dalamnya eksplorasi, elaborasi, dan konfirmasi; setelah itu kegiatan penutup. ${ }^{11}$ Hal ini diperjelas dan dipertegas lagi oleh Smith dan Ragan yang mengatakan bahwa kegiatan pembelajaran mencakup empat peristiwa, yang disebut dengan "expanded instructional event." Adapun kegiatan atau proses tersebut adalah adanya pendahuluan, pokok, kesimpulan, dan penilaian. ${ }^{12}$

Hamdayana disini sepertinya juga sependapat dengan pendapat-pendapat di atas, menurut Hamdayana untuk mencapai suatau kompetensi dasar harus dibagi dan perjelas Langkah-langkah kegiatan pada setiap pertemuan. Menurutnya Langkah-langkah itu adalah kegiatan pendahuluan yang meliputi orientasi, apersepsi, motivasi, pemberian acuan, pembagian kelompok belajar dan penjelasan skema atau mekanisme pelaksanaan pembelajaran. Selanjutnya adalah kegiatan inti yang berisi langkah kegiatan yang sistematis yang akan dilalui oleh siswa untuk mengkontruksi ilmu sesuai dengan skema yang telah ditentunan dan disusun. Langkah-langkah tersebut seyogyanya disusun dengan sebaik mungkin agar siswa dapat menampilkan perubahan tingkah laku sebagaimana yang telah dicantumkan pada tujuan pembelajaran dan indikator pembelajaran. Dan yang terakhir adalah kegiatan penutup, pada kegiatan ini guru hendaknya memberikan intruksi kepada siswa agar membuat kesimpulan, guru mengoreksi dan mengecek hasil belajar siswa, dan guru juga hendaknya memberikan intruksi tindak lanjut pembelajaran. ${ }^{13}$

Dari paparan di atas dapat dipahami bahwa pelaksanaan atau proses pembelajaran setidaknya ada kegiatan pendahuluan, penyampaian materi, dan penutup. Hal ini sebagaimana yang telah dilakukan oleh HMP PBA STIQ Amuntai dalam pembelajaran maharah istima' dan maharah kalam, yang pada pelaksanaan pembelajaran membagi atau mengalokasi waktunya menjadi beberapa bagian. Ada kegiatan pendahuluan, penyampaian materi, dan kegiatan penutup. Pada penyampain materi para pengajar menggunakan metode yang sesuai dengan materi yang disampaikan, namun setelah penulis observasi dan wawancara dengan pihak HMP mengatakan bahwa metode yang digunakan adalah metode demonstrasi, karena dalam pembelajaran mharah istima' dan maharah kalam lebih banyak praktik, oleh karena itu sebelum praktik secara langsung mereka diberikan contoh terlebih dahulu oleh guru atau penagajar tersebut.

Selain menggunakan metode, para pengajar juga menggunakan media, yangmana media ini sangat membantu jalannya proses pembelajaran maharah istima' dan kalam. Adapun media

\footnotetext{
11 "Peraturan Menteri Pendidikan Nasional Republik Indonesia Nomor 41 Tahun 2007," t.t.

12 Patricia L Smith dan Tillman J Ragan, Instructional Design (NY: John Wiley \& Sons, 2004).

13 Jumanta Hamdayama, Metodologi Pengajaran (Jakarta: PT Bumi Aksara, 2016), h. 24-26.
}

Al Qalam: Jurnal Ilmiah Keagamaan dan Kemasyarakatan Vol. 16, No. 2 Maret - April 2022 
H. Alfianor, Lc., M.Pd.I: Pengelolaan Pembelajaran Maharah Istima' dan Kalam Oleh Himpunan Mahasiswa Prodi PBA STIQ Amuntai

yang digunakan adalah media audio dan media visual, mungkin yang dimaksud adalah media audio visual, yang mana jika dilihat dari materi dan pembelajarannya adalah maharah istima' dan maharah kalam, maka dalam pembelajarannya pun sangat mendukung dengan adanya media audio visual. Para peserta didik tentunya diperdengarkan materi-materi yang berkaitan dengan istima' dengan menggunakan media audio, dan ketika materi kalam, para peserta didik diperlihatkan video tentang percakapan atau kalam.

Dalam suatu proses pembelajaran tentunya selain materi yang sudah dipersiapkan dengan matang juga membutuhkan metode dan media yang mendukung kelancaran jalannya proses penyampaian materi. Metode itu sendiri dapat diartikan sebagai suatu cara yang sistematis dan sudah terpikirkan dengan baik dan matang untuk bisa mencapai suatu tujuan yang hendak dicapai. ${ }^{14}$ Di dalam bahasa Arab metode disebut dengan at-Tahariqah yang berarti jalan atau langkah-langkah strategis yang telah disusun dan disiapkan untuk melaksanakan suatu pekerjaan. Sehingga dengan begitu metode dapat dipahami bahwa metode adalah suatu cara atau jalan yang harus dilalui atau ditempuh untuk bisa mencapai suatu tujuan. ${ }^{15}$

Menurut Samiudin, bahwa metode sangatlah penting untuk mencapai tujuan pembelajaran. Menurutnya tujuan merupakan salah satu keinginan atau cita-cita yang hendak dicapai pada kegiatan pembelajaran. Lebih lanjut, tujuan juga diibaratkan sebagai suatu pedoman yang akan memberikan rambu-rambu atau arah kemana kegiatan pembelajaran akan dibawa. Dalam mengembangkan kegiatan pembelajaran tentunya seorang pendidik memiliki tujuan yang hendak dicapai, dan tentunya guru pasti berusaha semaksimal mungkin agar bisa mencapai tujuan tersebut. Oleh karena itu, metode sangatlah tepat dan penting untuk menjadi salah satu alat untuk mencapai suatu tujuan pembelajaran. Jika diibaratkan metode itu seperti pelican jalan, jalannya proses pembelajaran agar bisa mencapai tujuan atau sasaran. Oleh karena itu, hendaknya guru menggunakan metode yang dapat membantu atau menunjang jalannya proses pembelajaran, sehingga dengan penggunaan metode yang tepat diharapkan mampu menjadikan sebagai alat yang efektif dan efisien untuk mencapai tujuan pembelajaran. ${ }^{16}$

3. Evaluasi Pembelajaran

Evaluasi merupakan kegiatan yang dilakukan oleh seorang pengajar setelah melaksanakan pembelajaran dengan tujuan untuk mengetahui informasi yang berkaitan dengan hasil belajar atau hasil pembelajaran yang telah dilaksanan. Sebagaimana yang dikatakan oleh Nunung Nuriyah,

${ }^{14}$ KBBI Offline versi 1.2 , t.t.

${ }^{15}$ Ramayulis, Metode Pendidikan Agama Islam (Jakarta: Kalam Mulia, 2005), h. 2.

${ }^{16}$ H Samiudin H Samiudin, "Peran Metode untuk Mencapai Tujuan Pembelajaran," Jurnal AlMurabbi 2, no. 1 (2016): 41-58.

Al Qalam: Jurnal Ilmiah Keagamaan dan Kemasyarakatan Vol. 16, No. 2 Maret - April 2022 
H. Alfianor, Lc., M.Pd.I: Pengelolaan Pembelajaran Maharah Istima' dan Kalam Oleh Himpunan Mahasiswa Prodi PBA STIQ Amuntai

evaluasi adalah suatu usaha yang dilakukan oleh seorang pengajar untuk memperoleh informasi tentang hasil belajar siswa secara menyeluruh, baik informasi tentang sikap, pengetahuan, konsep, nilai, maupuan keterampilan proses. Hal ini tentunya sangat penting dan berguna bagi guru untuk menentukan kelanjutan pembelajaran, sebagai umpan balik, serta dapat menentukan strategi pembelajaran yang tepat bagi siswa. Oleh karena itu guru perlu mengadakan peneliaian, baik penilaian proses maupuan penilaian terhadap hasil belajar siswa. ${ }^{17}$

Hal ini sebagaimana yang dikatakan oleh ketua HMP PBA STIQ Amuntai,

Sedangkan tahap evaluasi ini dengan menampilkan siswa atau peserta didik beribicara di muka umum.

Menurut Idrus L mengatakan bahwa evaluasi merupakan hal yang tidak bisa dipisahkan dari proses atau kegiatan pembelajaran, karena evaluasi merupakan bagian dari proses pembelajaran, sehingga pelaksanaan evaluasi dalam kegiatan pendidikan merupakan hal yang sangat utama dan memiliki arti penting bagi pendidikan. Alasan lain juga karena evaluasi adalah suatu alat ukur atau kegiatan untuk mengatahui tingkat keberhasilan pembelajaran siswa atas materi atau pembelajaran yang telah dipelajari, disampaikan oleh guru, sehingga dengan dilakukannya evaluasi pembelajaran makan akan diketahui secara akurat dan meyakinkan. ${ }^{18}$

Menurut Sudirman N, dkk, bahwa tujuan dari diadakannnya evaluasi atau penilaian dalam proses pembelajaran adalah untuk mengambil keputusan tentang hasil belajar, untuk memahami siswa, dan untuk mengembangkan dan memperbaiki program pembelajaran yang telah dilaksanakan sebelumnya. ${ }^{19}$ Adapun syarat-syarat dalam penyusunan tes yaitu validitas, reliabilitas, daya beda butir, efektifitas, objektivitas. Sedangkan teknik evaluasi itu ada dua hal yaitu tes dan non tes. Tes merupakan beberapa jumlah pertanyaan yang mempunyai jawaban salah dan benar, sedangkan non tes lebih mengarah kepada tiga ranah yaitu ranah kognitif, afektif dan psikomotorik. $^{20}$

Daryanto menjelaskan lebih spesifik lagi terkait dengan teknik evaluasi, menurutnya Teknik evaluasi dibagi menjadi dua macam, yaitu teknik tes dan teknik non tes. Teknik tes adalah aktivitas yang dilakukan untuk mengetahui dan mengumpulkan informasi dan sifatnya lebih resmi dan memiliki batasan-batasan. Jika ditinjau dari segi kegunaan untuk mengukur siswa, maka

${ }^{17}$ Nunung Nuriyah, "Evaluasi Pembelajaran: Sebuah Kajian Teori," Edueksos: Jurnal Pendidikan Sosial \& Ekonomi 3, no. 1 (2016). (2019): 1.

${ }^{18}$ L Idrus, "Evaluasi dalam Proses Pembelajaran," Jurnal Manajemen Pendidikan Islam 9, no. 2

${ }^{19}$ Sudirman, Ilmu Pendidikan (Bandung: Sinar Baru, 2005), h. 242.

${ }^{20}$ Idrus, "Evaluasi dalam Proses Pembelajaran."

Al Qalam: Jurnal Ilmiah Keagamaan dan Kemasyarakatan Vol. 16, No. 2

Maret - April 2022 
H. Alfianor, Lc., M.Pd.I: Pengelolaan Pembelajaran Maharah Istima' dan Kalam Oleh Himpunan Mahasiswa Prodi PBA STIQ Amuntai

dapat dibedakan menjadi tiha macam, yaitu tes diagnostic, tes formatif, dan tes sumatif. Adapun untuk teknik non tes dapat dirincikan menjadi skala bertingkat, kuesioner, daftar cocok, wawancara, pengamatan dan riwayat hidup. ${ }^{21}$

Jika dilihat dari hasil observasi dan wawancara dengan ketua HMP PBA STIQ Amuntai belum terlihat adanya teknik evaluasi yang tersusun dan terstuktur yang sesuai dengan tujuan pembelajaran. Seharunya di dalam perencanaan pembelajaran evaluasi pembelajaran sudah ditentukan dan disusun dengan baik dan benar-benar dapat mengukur apakah tujuan dari pembelajaran sudah benar-benar tercapai. Dengan begitu, tujuan dan materi pembelajaran yang telah disampaikan oleh guru dapat diketahui dan terlihat dengan akurat dan meyakinkan. Sehingga hasil tersebut dapat dijadikan acukan sebagai timbal balik, perbaikan proses pembelajaran, perbaikan strategi dan metode pembelajaran, dan hal-hal yang perlu dipersipakan dengan baik dan matang.

\section{SIMPULAN}

Dari hasil uraian di atas maka penulis dapat simpulkan bahwa pengelolaan pembelajaran maharah istima' dan maharah kalam oleh HMP PBA STIQ Amuntai sudah tersusun secara terstruktur dan berjalan dengan baik. Namun, ada beberapa hal yang masih belum terpenuhi sebagaimana layaknya pengelolaan pembelajaran yang baik dan benar. Seperti halnya belum adanya penyusunan evaluasi pembelajaran yang benar-benar dapat mengukur dan mengetahui berhasilnya suatu pembelajaran.

Penelitian diharapkan dapat memberikan kontribusi kepada para pengajar dimanapun berada, baik secara teoretis maupun secara praktis. Sehingga diharapkan juga dengan adanya penelitian ini bisa menjadi masukan bagi HMP PBA STIQ Amuntai untuk lebih menyempurnakan dan memperbaiki program atau pengelolaan pembelajaran maharah istima' dan maharah kalam.

\section{Daftar Pustaka}

Daryanto. Evaluasi Pendidikan. Jakarta: Rineka Cipta, 2013.

Djabidi, Faizal. Manajemen Pengelolaan Kelas. Malang: Madani, 2017.

Hamalik, Oemar. Perencanaan Pengajaran Berdasarkan Sistem. Jakarta: PT Bumi Aksara, 2009. Hamdayama, Jumanta. Metodologi Pengajaran. Jakarta: PT Bumi Aksara, 2016.

Idrus, L. "Evaluasi dalam Proses Pembelajaran.” Jurnal Manajemen Pendidikan Islam 9, no. 2 (2019): 1 .

${ }^{21}$ Daryanto, Evaluasi Pendidikan (Jakarta: Rineka Cipta, 2013), h. 28.

Al Qalam: Jurnal Ilmiah Keagamaan dan Kemasyarakatan Vol. 16, No. 2 Maret - April 2022 
H. Alfianor, Lc., M.Pd.I: Pengelolaan Pembelajaran Maharah Istima' dan Kalam Oleh Himpunan Mahasiswa Prodi PBA STIQ Amuntai

KBBI Offline versi 1.2, t.t.

Majid, Abdul. Perencanaan Pembelajaran. Bandung: PT Remaja Rosdakarya, 2007.

_. Perencanaan Pembelajaran. Bandung: Remaja Rosdakarya, 2011.

Nuriyah, Nunung. "Evaluasi Pembelajaran: Sebuah Kajian Teori." Edueksos: Jurnal Pendidikan Sosial \& Ekonomi 3, no. 1 (2016).

Nurlaila. "Urgensi Perencanaan Pembelajaran Dalam Peningkatan Profesionalisme Guru." Jurnal Ilmiah Sustainable 1, no. 1 (2018).

"Peraturan Menteri Pendidikan Nasional Republik Indonesia Nomor 41 Tahun 2007," t.t.

Ramayulis. Metode Pendidikan Agama Islam. Jakarta: Kalam Mulia, 2005.

Samiudin, H Samiudin H. "Peran Metode untuk Mencapai Tujuan Pembelajaran." Jurnal AlMurabbi 2, no. 1 (2016): 41-58.

Sanjaya, Wina. Perencanaan dan Desain Sistem Pembelajaran. Jakarta: Kencana, 2015.

Setyosari, Punaji. "Pembelajaran Kolaborasi Landasan untuk Mengembangkan Keterampilan Sosial, Rasa Saling Menghargai dan Tanggung Jawab.” Pidato Pengukuhan Pendidik Besar dalam Bidang Ilmu TEP pada FIP UM disampaikan pada sidang terbuka Senat UM 14 (2009).

Smith, Patricia L, dan Tillman J Ragan. Instructional Design. NY: John Wiley \& Sons, 2004.

Sudirman. Ilmu Pendidikan. Bandung: Sinar Baru, 2005.

Al Qalam: Jurnal Ilmiah Keagamaan dan Kemasyarakatan Vol. 16, No. 2

Maret - April 2022 